\title{
The effect of physical training program on body composition and body mass index
}

\author{
Bashar Jasim AL-juwari, Hussam Qahtan \\ Nursing College, University of Mosul.
}

(Ann. Coll. Med. Mosul 2010; 36 (1 \& 2): 18-25).

Received: $5^{\text {th }}$ Apr 2010; Accepted: $30^{\text {th }}$ Jan 2011.

\begin{abstract}
Objectives: To evaluate the effect of physical training program on body composition and body mass index, and to evaluate the body mass index as predictor of body fat in young adults.

Material and methods: Prospective was done at the College of Physical Education - University of Mosul, first year students (100) male and (22) female were participated in this study. A physical training program of 2 hours (aerobic exercise) daily for 4 days per week for 4 months. Medical height and weight scales (Detector) and bio-electrical impedance analysis measurements device(Quantum П) were used for measurements.
\end{abstract}

Results: Physical training program has significant effect on body weight, BMI and free fat mass, but has no significant effect on fat mass.

Conclusions: Physical training program increase BMI and free fat mass but has no significant effect on fat mass. BMI is a specific test for overweight and obesity but it is not a sensitive test.

Keywords: BMI, physical training program, body composition.

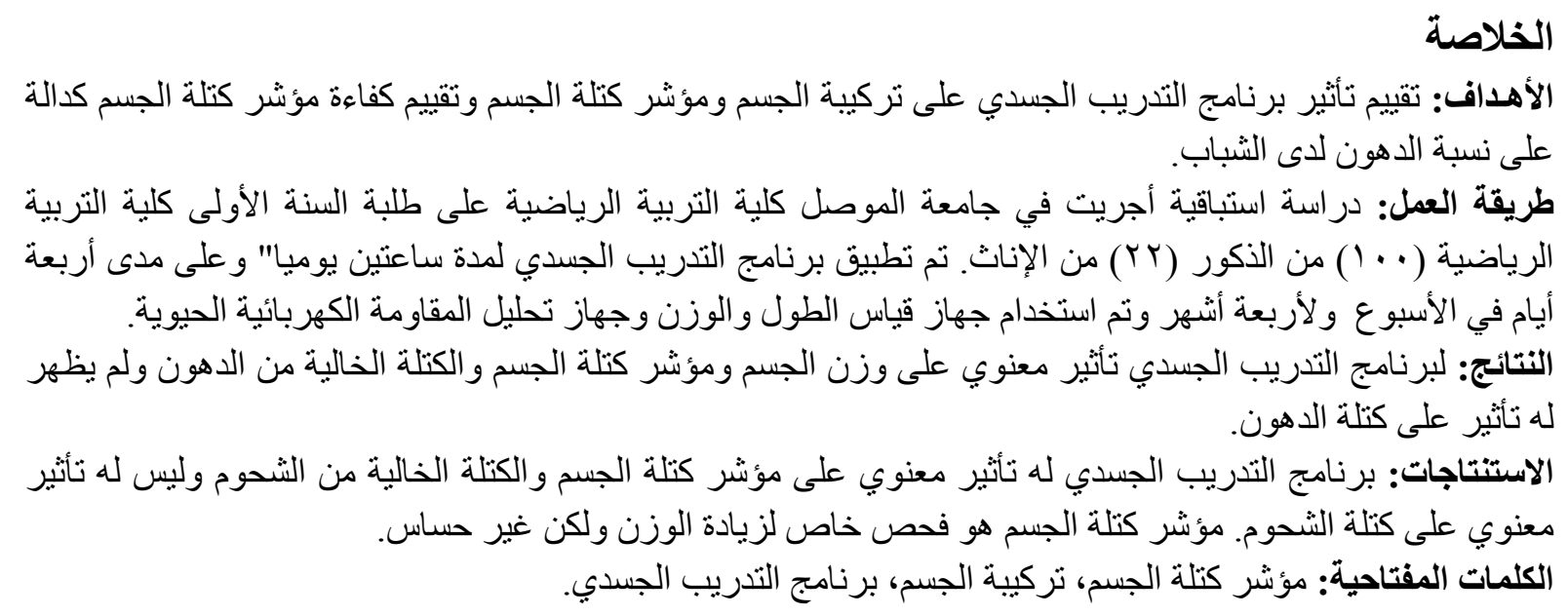

besity is a world wide public health problem, and its great increase is mainly due to the increases in energy consumption owing to availability of food of high caloric density and to the reduction of energy expenditure by regular physical activities ${ }^{1-6}$. Observational and experimental studies have shown beyond doubt the growing prevalence of obesity. Obesity occurs in an individual when body fat is very high relative to the lean body mass and is defined as a body mass index $(\mathrm{BMI}) \geq\left(30 \mathrm{Kg} / \mathrm{m}^{2}\right)^{(7,8)}$.

Absolute prevalence has been observed across the globe over the past few decades ${ }^{(9)}$. 
The WHO estimates that over a billion adults are over-weight and over 30 . millions are obese world wide. We are facing a global obesity crisis ${ }^{(10,11)}$.

Obesity means having too much body fat. It is different from being over weight which means weighing too much, the weight comes from muscle, bone, fat and / or body water. Both terms mean that a person's weight is greater than what's considered healthy for his or her height ${ }^{(12,13)}$.

The national Health and Nutrition Examination Survey (NHANES) reports that the prevalence of obesity has doubled over the last 25 years, based on direct height and body - weight measurements ${ }^{(14,15)}$.

Obesity is a cause of major morbidity and mortality ${ }^{(16,17)}$; it is associated with numerous co-morbidities such as cardiovascular disease, type 2 diabetes, hypertension, certain cancers, sleep apnea, osteoarthritis and reduced life expectancy ${ }^{(18-21)}$.

$\mathrm{BMI}$ is a calculation based on height, weight and gender specific in adults. It does not directly measure the percentage of body fat, but it is a more accurate indicator of over weight and obesity that relying on weight alone (22).

Bioelectrical impedance analysis is another method of assessing body fat percentage. There is a variety of body composition and body fat analyzer and scales available that provide more than just total weight measurements. It determines total weight measurements, the percent and amount of body fat, muscle mass, water and even bone mass ${ }^{(23)}$

Eating disorder clinics and fitness centers use more sophisticated tests such as bioelectrical impedance analysis that calculate lean body mass, body fat, and total body water based on changes in conduction of all applied electrical current ${ }^{(24)}$.

When weight is lost too rapidly or by significant reductions in energy intake, lean muscle mass will be lost, which can affect performance negatively ${ }^{(25,26)}$.

The National Institute of Health recommends, that a healthy adult male's body should have between $13-17 \%$ fat , a healthy female's body should be composed of $25 \%$ fat ${ }^{(27)}$.

Objectives: To evaluate the effect of physical training program on body composition and body mass index, and to evaluate the body mass index as predictor of body fat in young adults.

\section{Methods}

The data were collected prospectively using experimental design. A simple stratified sample consists of 122 students (100 males and 22 females) from first year of the College of Physical Education- University of Mosul.

The pre test started at $1^{\text {st }}$ Dec. 2008 for one month, standard scale (medical Decto scale, USA origin) is used for measuring the height and weight of adults, was used in order to identify the BMI levels. The weight was measured in kilograms and the height was measured in meters.

Using the following formula to calculate the BMI:

$$
\mathrm{EMI}=\frac{\text { Weight in kilogram }}{{\text { (Height } \text { in meters })^{2}}^{2}}
$$

Body composition was examined by using of Bio - electrical impedance analysis device (Quantum $\Pi$ - USA origin); available at Nursing College and College of Physical Education- University of Mosul. The following circumferences in the body were measured, neck, chest, abdomen, hip, right arm, right thigh, right calf circumferences.

\section{Body composition measurements}

a. Fat percentage.

b. Fat weight $(\mathrm{kg})$.

c. Free fat percentage.

d. Free fat weight.

e. BMI.

The results of Segal study 1998 confirms the validity of BIA and indicate that the precision of predicting LBM and FFM from impedance, can be enhanced by sex and fatness-specific equations ${ }^{(28)}$. 
The following guideline were applied before Bio-electrical impedance analysis measurement:

1- No eating or drinking within 4 hours of the test.

2- No exercise within 12 hours of the test.

3- Urinate within 30 minutes of the test.

4- No alcohol consumption within 48 hours.

5- No Diuretic within 7 days.

The BIA test starts by lying the student on testing table, and electrodes are connected to the hands and feet, electrolyte gel is applied, then a current of $50 \mathrm{KH} 2$ is introduced. Selecting the appropriate equation to determine the quality of the results and minimize variables. Average time for conducting this test is about 10 minutes BIA is used to determine body weight, $\mathrm{BF} \%$, free fat mass.

According to the College of Physical Education curriculum; a physical training program of 2 hours of aerobic exercise with strength training (moderate practice at the beginning and increased gradually) for 4 days a week for 4 months is practiced. The post test started on the $1^{\text {st }}$ April 2009, BMI and BIA was also examined in the same manner for one month.

\section{Results}

Table (1) shows significant difference of physical training program on mean body weight, BMI and free fat but no significant difference on fat mass.

Table (2) shows anthropometric measurements in male pre and post physical training program by using $\mathrm{BMI}$, and bio electrical impedance analysis to determine $\mathrm{BF} \%$.
BMI classify $82 \%$ of students within normal range, while actually $42 \%$ of them are within normal range by using BIA for estimating of body fat. After physical training program (post test) there is an increase of the over weight and obese students, while there in decrease in the number of over weight and obese students by using BIA for estimating body fat. The mean $\mathrm{BMI}$ is (22) and mean body fat is (21) in pre physical training program while the mean BMI is (23) and mean body fat is (16) in post physical training program.

Table (3) shows the anthropometric measurements in female pre and post physical training program $\mathrm{BMI}, \mathrm{BF} \%$.

It shows that $68 \%$ of females are within normal range of weight by using of BMI, while $28 \%$ only are within normal range by using of $\mathrm{BIA}$, in contrast to $18 \%$ are overweight by using $\mathrm{BMI}$ and $45 \%$ are over weight by using BIA.

No great difference is seen in post training program by the use of $\mathrm{BMI}$ and $\mathrm{BIA}$, and the mean BMI is (22) in pre and post physical training program.

The mean body fat is (47) in pre physical training program while it is (38) in post physical training program by using of bio electrical impendence analysis.

Table (4) shows the sensitivity and specificity of BMI.

It represent the sensitivity and specificity of $\mathrm{BMI}$ in males and females according to $\mathrm{WHO}$ criteria. The mean specificity is $87.5 \%$ in males compared with $84.9 \%$ in females, while mean sensitivity is $30.2 \%$ in males and $32 \%$ in females, it indicate that BMI is a specific test but it is not a sensitive test for overweight and obesity.

Table (1): The effect of physical training program.

\begin{tabular}{|c|c|c|c|c|c|c|}
\hline Categories & Physical training program & No. & $\mathrm{x}$ & SD & t.cal & P. Value \\
\hline \multirow{2}{*}{ Body weight } & Pre & 122 & 64.94 & 9.6 & \multirow{2}{*}{2.9} & 0.05 \\
\hline & Post & 122 & 65.81 & 9.9 & & Sig \\
\hline \multirow{2}{*}{ BMI } & Pre & 122 & 22 & 9 & \multirow{2}{*}{3.6} & 0.05 \\
\hline & Post & 122 & 23 & 10.4 & & Sig \\
\hline \multirow{2}{*}{ Fat mass } & Pre & 122 & 12.3 & 5.6 & \multirow{2}{*}{1.5} & 0.05 \\
\hline & Post & 122 & 11.35 & 5.8 & & N.S \\
\hline \multirow{2}{*}{$\begin{array}{l}\text { Fat free } \\
\text { mass }\end{array}$} & Pre & 122 & 80.2 & 11.9 & \multirow{2}{*}{3.5} & 0.05 \\
\hline & Post & 122 & 83.6 & 7.4 & & Sig \\
\hline
\end{tabular}

$d f=121$, t. critical $=2.6, X=$ mean weight in kilograms 
Table (2): Male anthropometric measurements in pre and post physical training program.

\begin{tabular}{|l|c|c|c|c|}
\hline \multirow{2}{*}{$\begin{array}{l}\text { Pre physical } \\
\text { training program }\end{array}$} & \multicolumn{2}{|c|}{ BMI } & \multicolumn{2}{c|}{ Body fat } \\
\cline { 2 - 5 } & no & $\%$ & no & $\%$ \\
\hline underweight & 1 & 1 & 4 & 4 \\
\hline normal & 82 & 82 & 42 & 42 \\
\hline overweight & 13 & 13 & 32 & 32 \\
\hline obese & 4 & 4 & 22 & 22 \\
\hline X- SD & $22-7.5$ & $2-3.6$ & $21-3.8$ & $13-0.6$ \\
\hline
\end{tabular}

\begin{tabular}{|l|c|c|c|c|}
\hline \multirow{2}{*}{$\begin{array}{l}\text { Post physical } \\
\text { training program. }\end{array}$} & \multicolumn{2}{|c|}{ BMI } & \multicolumn{2}{c|}{ Body fat } \\
\cline { 2 - 5 } & no & $\%$ & no & $\%$ \\
\hline underweight & 4 & 4 & 2 & 2 \\
\hline normal & 73 & 73 & 57 & 57 \\
\hline overweight & 15 & 15 & 24 & 24 \\
\hline obese & 8 & 8 & 17 & 17 \\
\hline X-SD & $23-1.55$ & $2-3$ & $16-6.5$ & $9-0.7$ \\
\hline
\end{tabular}

Table (3): Female anthropometric measurements in pre and post physical training program.

\begin{tabular}{|l|c|c|c|c|}
\hline \multirow{2}{*}{$\begin{array}{c}\text { Pre physical } \\
\text { training program. }\end{array}$} & \multicolumn{2}{|c|}{ BMI } & \multicolumn{2}{c|}{ Body fat } \\
\cline { 2 - 5 } & no & $\%$ & no & $\%$ \\
\hline underweight & 1 & 4 & 0 & 0 \\
\hline normal & 15 & 68 & 6 & 28 \\
\hline overweight & 4 & 18 & 10 & 45 \\
\hline obese & 2 & 10 & 6 & 27 \\
\hline X-SD & $22-4.4$ & $3-2.9$ & $47-5.2$ & $18-0.6$ \\
\hline
\end{tabular}

\begin{tabular}{|l|c|c|c|c|}
\hline \multirow{2}{*}{$\begin{array}{l}\text { Post physical } \\
\text { training program. }\end{array}$} & \multicolumn{2}{|c|}{ BMI } & \multicolumn{2}{c|}{ Body fat } \\
\cline { 2 - 5 } & no & $\%$ & no & $\%$ \\
\hline underweight & 2 & 10 & 0 & 0 \\
\hline normal & 13 & 59 & 6 & 28 \\
\hline overweight & 4 & 18 & 11 & 49 \\
\hline obese & 3 & 13 & 5 & 22 \\
\hline X-SD & $22-5.2$ & $3-12$ & $38-5.9$ & $15-3.6$ \\
\hline
\end{tabular}

Table (4): The sensitivity and specificity of BMI in male and female.

\begin{tabular}{|l|c|c|c|c|}
\hline & \multicolumn{2}{|c|}{ Male } & \multicolumn{2}{c|}{ Female } \\
\hline \multicolumn{1}{|c|}{ BMI } & Specificity & Sensitivity & Specificity & Sensitivity \\
\hline$<18.5$ & $96 \%$ & $3 \%$ & $90.5 \%$ & $9.5 \%$ \\
\hline $18.5-24.9$ & $77.5 \%$ & $100 \%$ & $68.5 \%$ & $100 \%$ \\
\hline $25.0-29.9$ & $84 \%$ & $13.3 \%$ & $96 \%$ & $4 \%$ \\
\hline$>30.0$ & $92.5 \%$ & $4.3 \%$ & $84.5 \%$ & $15 \%$ \\
\hline Mean & $87.5 \%$ & $30.2 \%$ & $84.9 \%$ & $32.1 \%$ \\
\hline
\end{tabular}

\section{Discussion}

Obesity is a cause of major morbidity and mortality. It is a chronic condition associated with increased cardio metabolic risk as well as number of obesity - related co morbidities. Achieving and maintaining weight reduction can have numerous positive effects, on overall health ${ }^{(29)}$.

There is universal support for the use of physical activity to decrease overweight and promote improved health ${ }^{(30,31)}$. An increase in physical activity is an important part of weight management program. Most weight loss occurs because of decreased caloric intake. Sustained physical activity is most helpful in preventing weight regain ${ }^{(32)}$.
There are reasons to become more informed about body composition:

- To develop complete physical fitness profile for clients.

- To monitor body fat loss and muscle growth resulting from exercise.

- To provide baseline data for nutritional counseling and treatment of obesity.

- To describe changes due to growth, development, maturation and aging.

- To maximize the performance of athletes $^{(33)}$.

Table (1) shows significant difference of physical training program on body weight, BMI and free fat mass, but no significant difference on fat mass. 
Physical activity has been shown to be inversely associated with BMI in numerous cross-sectional studies, and obese subjects have been observed to be physically less active than non-obese. However, in some studies No association between physical activity and BMI has been found or an inverse association has been observed only in women $^{(34,35)}$.

Table (2) shows anthropometric measurements in males pre and post physical training program by using $\mathrm{BMI}$, and bio electrical impedance analysis to determine $\mathrm{BF} \%$.

The athlete's weight should typically fall between the $25^{\text {th }}$ and $75^{\text {th }}$ percentile of weight for height for age (by Nationals center for health statistics guidelines), although some athletes weigh more because of increase muscles mass, the use of BMI in athletes is not recommended ${ }^{(36,37)}$.

BMI demonstrates low or no correlation with other methods for assessing overweight and obesity, BMI identifies fewer obese subjects than other methods ${ }^{(38)}$.

WHO suggest the use of BMI as a method of choice to determine over weight, it is an adequate method, its index ranges from malnutrition to grade $Ш$ obesity, However, fat content, which is the most important factor in terms of associated chronic disease may oscillate widely within the same BMI value ${ }^{(39)}$.

Table (3) shows the female anthropometric measurements in pre and post physical training program. Significantly higher associations exist in each gender between $\mathrm{BMI}$ and $\mathrm{BF} \%$ in the upper BMI textile than in the lower BMI textile. In the lower BMI textile, the correlations between BMI and FFM were approximately twice as large as those between $\mathrm{BMI}$ and $\mathrm{BF} \%$, the BMI correctly identified $44 \%$ of obese men and $52 \%$ of obese women, when obesity was determined from $\mathrm{BF} \%$, BMI is an uncertain diagnostic index of obesity ${ }^{(40)}$.

Average men have more skeletal muscles than average women and average women have more fat than average men ${ }^{(41,42)}$.

Jackson 2002 study show there is an average BMI gap of $2.3 \mathrm{~kg} / \mathrm{m}^{2}$ between men and woman, body fat $25 \%$ for men, $33 \%$ for woman $^{(43)}$, while Deureberg 2001 study shows overweight women tend to have higher BMI values than over weight men ${ }^{(44)}$

The mean BMI in men is not necessarily that different from BMI in women; body composition does vary by gender, men have more skeletal muscle than women - both in absolute terms and relative to body mass. The differences have been found to be greater in the upper body ${ }^{(45)}$.

Table (4) represents the sensitivity and specificity of BMI in males and females according to $\mathrm{WHO}$ criteria. It indicates that BMI is a specific test but it is not a sensitive test for overweight and obesity. This result is in agreement with Dietiz study 1998 which show that the BMI has a poor sensitivity to screen for overweight ${ }^{(46)}$.

Sensitivity is given more importance than specificity since false positive overweight is not considered as serious as a false negative overweight ${ }^{(47)}$.

The use of BMI to screen for overweight / obesity can generate a high percentage of false positive male and even higher percentage of false negative female, a more universal approach to using anthropometric measure to screen for overweight / obesity should be developed ${ }^{(40)}$.

BMI a number tested a formula for calculating weight for height is significantly associated with total body fat content and should be used to monitor changes in body weight or to assess overweight or obesity, the calculated $\mathrm{BMI}$ is a common clinical Index of obesity or altered body fat distribution. A well accepted scale has been developed to calculate by gender using weight-to-height ratios ${ }^{(48)}$.

BMI continues to serve well for many purposes, but the time is now right to initiate a gradual evolution beyond BMI toward standards, based on actual measurement of body fat mass ${ }^{(49)}$.

\section{Conclusions}

Increased physical activity has significant effect on body weight, so sustained physical activity is most helpful in the prevention of weight regain.

Anthropometry has the advantage of being a measuring tool involving less time and 
operational costs than other more complex methods, However, BMI fails to distinguish between lean body mass and fat, thus the relationship between BMI and body fatness varies according to body composition properties.

BIA is a method of choice to determine body fat. One draw back of using BIA method is the equipment is relatively expensive $(\$ 3,500)$.

\section{Recommendations}

- Physicians should understand body composition measurement, and be willing to educate athletes, about nutritional consultation and physical training programs.

- Results are consistent with published data showing the need to consider the age and sex as an open defining the prevalence of obesity with BMI.

- BIA should be considered as a method of choice to determine overweight and obese people according to fat mass.

\section{Refferences}

1. Hyattsvill M D. National center for health statistics. Healthy people 2000 final review (online). Hyattsville MD: Publichealth services. http://www.cdc. gov/nchs/hb2000/hp2ko-acc.pdf. Accessed on march 17, 2007.

2. Rigby N . "Commantary; Counterpoint to campos". Int Journal Epidemiol 2006; 35:79- 80.

3. Nicholas A, Nicki R, Brian R, and walker. Management of obesity. Davidson's principles and practice of medicine, $20^{\text {th }}$ edition, Missouri, Mosby 2006;547-590.

4. Brunt M. "Female athlete traid". Clin sports Med $2005 \mathrm{Jul} ;$ 24(3):623 - 36.

5. Fridman J. A war on obesity, not the obese. Science 2003; 299: 856 - 858.

6. Pai M, Paloucek F. The origin of the "Ideal Body weight equations". Ann pharmacol 2000 34:1066-69.

7. Centers for Disease control and prevention. U.S obesity Trends 19852006; http\|: www.cdc.gov/nccdphp/ dnpa/ obesity/treat/maps/. Accessed March 5, 2008.
8. Jeffery RW, Sherwood NE. Is the obesity epidemic exaggerated ? BMJ 2008; 336:245.

9. WHO. Global database on body mass index . www.who.int / bmi /index.jsp.

10. Hedley AA, Ogden CL, Johnson CL et al. Prevalence of overweight and obesity among US children, adolescent, and adult 1999-2002. JAMA 2004; 2910: 2847-50.

11. Flegal KM, Carroll MD, Ogden CL. et al. Prevalence and trends in obesity among US adults.1990-2000. JAMA 2002 ; 288: 1723-1727.

12. Hulens N, Vansant G, and Lysens R. "Exercise capacity in lean versus obese women", Scand Journal Medical Science sports 2001; 11: 305 $-309$.

13. Swinburn B, Caterson I, Seidell J, and James W. "Diet, Nutrition and the prevention of excess weight gain and obesity". Public health Nutr 2004; $7(1 \mathrm{~A}): 123-46$.

14. Centers for Disease control and prevention. National center for Health statistics. Prevalence of overweight and obesity among adults: United States 2003-2004.

15. Morley A. "Medline plus Medical Encyclopedia: weight management (http://www.nim.gov/medlineplus/ency/ article/oo1943.htm" 2007; pp. 11 - 17.

16. Haffiner SM. abdominal adiposity and cardiometabolic risk: do we have all the answers ? Am J med 2007; 120 (suppll): 10-16.

17. Reilly J M, Methven E, McDowell Z, Hacking B, Alexander D, Stewart L. "Health onsequences of obesity". Arch Dis child 2003; 88(9): 748 - 52.

18. Poirierp, Giles TD, Bray GA, Hong Y, stern JS, pisunyer FX, Eckel RH. obesity and cardiovascular Disease Circulation 2006;133;898-918.

19. Richardo E, Behrman L, and Robert M. "Nelson Essentials of pediatrics" copyright $^{\odot} 2002$ by W.B. Saunder company,597-612. 
20. Despres J, Couillard C, Gagnon J, and Race. Visceral adipose tissue, plasma lipids, and lipoprotein lipase activity in men and women: the health, Risk Factors, Exercise Training, and Genetics (HERITAGE) family study. Arterioscler Thromb vasc Biol. 2000; 20: 1932 - 1938.

21. Fox C, Massavo J, and Hoffmann U. "Abdominal and subcutaneous Adipose Tissue compartments". Association with metabolic Risk Factors in the Framingham_Heart Study Circulation. Jun 2007;18.

22. Taylor R, Keil D, Cold E, Williams S, Goulding A .Body mass index, waist girth, and waist-to-hip ratio as indexes of total and regional adiposity in women: evaluation using receiver operating characteristic curves, American Medical Journal Clin Nutr 1998; 67: $44-9$.

23. Sundquist J, and Johansson S. "The influence of socioeconomic status, ethnicity and life style on body mass index in a longitudinal study". Int Journal Epidemiol, 1998; 27: 57 - 63.

24. Barbara k. obesity management. fundamental nursing skills and concepts $.4^{\text {th }}$ edition Prentice Hall, $2005 ; 2439$.

25. Chodzko- Zajko W. "committee on Nutrition. Sports nutrition". American Academy of_pediatrics 2004; 155 166.

26. U.S. Department of health and Human services. "Clinical Guidelines on the Identification, Evaluation, and Treatment of overweight and obesity in adults" The Evidence Reports, NIH publication No. 98 - 4083 (online). National Heart. Lung and blood institute http:// www.nhlbi.nih.gov/ quidelines/obesity/obgdlns.pdf, 2007; 6-9.

27. Montana M. "physiology and psychology: performance Benchmarks - Body composition 2007; 274-288 (http:// btc.montana. edu/olympics /physiology/pb03. html).
28. Segal K, Van Loan M, Fitzgerald P. "Lean body mass estimation by bioelectrical impedance analysis a four - site cross - Validation study". American Medical Journal Clin Ntur. 1998; (47): 7 - 14.

29. BMJ Middle east CME program obesity pharmacological management. May 2008;15 (160).

30. Tyler C, Johnston CA, Foreyt JP. Themed Review: lifestyle. Management of obesity. Am J lifestyle Med. 2007; 1(6):423-429.

31. Pi-sunyer FX. use of lifestyle changes treatment plans and drug therapy in controlling Cardiovascular and metabolic risk factors. Obesity. 2006; 14 (suppl 3): 135-142 .

32. Wilmore J, Brownell K, and Rodin J. Body weight and body composition. Body weight and performance in Athletes: Disorders of Modern Society. Philadelphia, PA: Lea and Febiger. $3^{\text {th }}$, edition, Mosby, Inc, 2001; 77 - 93.

33. Suh J. "Adipose is a conserved dosage - sensitive Ant obesity Gene" Cell Metabolism American Medical Journal 2007;6(3): $195-207$.

34. Fentem $P$, and Mockett S. "Physical activity and body composition: what do the national surveys reveal"? Int Journal Obes Relat Metab Disord 1998;(22) Suppl $2: 58$ - 514.

35. Canadian Fitness and lifestyle research Institute. Physical activity and obesity. 2005; $94-11$.

36. Bagust A, and Walley T. "An altenative to body mass index for standardizing body weight for stature". British Medical Journal, sep 2000; 93(9):589 - 95.

37. Sevendsen O. "Should measurement of body composition influence therapy for obesity"? Actadiabetol, 2003; 40: S250 - 3 .

38. Gu D, Duan X. "Body weight and mortality among men and women in china". Journal American Medical Association 2006; 295:779 - 83. 
39. World Health Organization (WHO). "Obesity preventing and managing the global epidemic of obesity" . Report of the WHO Consultation of obesity. Geneva. 2006; 3 - 5.

40. Reilly JM, Methven E, McDowell Z, Hacking B, Alexander D,Stewart L."Health Consequences of obesity". Arch Dis child 2003; 88(9): $748-52$.

41. Kuczmarski M, Kuczmarski $R$, and Naijar M. "Effects of age on validity of self - reported height, weight, and body mass index: Findings from the third National health and Nutrition Examination survey", 1988 - 1994. Journal American Medical Diet Association 2001; 101:28 - 34.

42. Molarius A, Seidell J. "Selection of anthropometric indicators for classification of abdominal fatness - a critical review". Int Journal obes Relat Metab Disord 1998; 22:719-27.

43. Jackson $A$, Stanforth $P$, and Gagnon $J$. "The effect of sex, age and race on estimating percentage body fat from body mass index : the Heritage family study". Int Journal obes Metab Disord, Jun 2002; 26(6): 789 - 96.
44. Deurenberg P, Andreol A, and Borg P. "The validity of predicted body fat percentage", Eur Journal Clin Ntur, Nov 2001; 5911:973 - 9.

45. Janssen L, Heymsfiled S, Wang Z, Ross R. "Skeletal muscle mass and distribution in 468 men and women aged 18-88 yr". Journal Appl physical $2000 ; 89: 81-88$.

46. Dietz W, Robinson T, "Use of the body mass index (BMI) as a measure of overweight in children and adolescents". Journal pediatr 1998; 132:191 - 193.

47. Wellens $R$, Roche $A$, Khamis $H$. "Relationships between the body mass index and body composition ". Journal Obes Res, Jan 1996; 4(1) :35-44.

48. 47. Ragavendra $R$, and Baliga. "250 cases in clinical Medicine", $3^{\text {rd }}$ edition, Mosby, Inc, 2002; 383 - 384, England.

49. Sampei M, Novo N, Juliano $y$, and Sigulem D. Body mass index. Int Journal Obes Relat Metab Disord, Mar 2001; 25(3). 